\title{
Analysis of the physical development and somatotype of girls and females involved into dancing and gymnastic sports
}

Podrigalo L.V. ${ }^{1,4 \mathrm{ABCDE}}$, Artemieva H.P. ${ }^{2 \mathrm{ABCD}}$, Rovnaya O.A. ${ }^{\mathrm{ABCD}}$, Panshyna A.D. ${ }^{2 \mathrm{ADE}}$, Ruban L.A. ${ }^{3 \mathrm{ADE}}$, Merkulova T.V. ${ }^{4 \mathrm{ADE}}$, Galashko M.M. ${ }^{5 \mathrm{ADE}}$, Chernukha O.V. ${ }^{6 \mathrm{ADE}}$

${ }^{1}$ Department Hygiene and Human Physiology, Kharkov State Academy of Physical Culture, Ukraine ${ }^{2}$ Department of Dance Sports, Fitness and Gymnastics, Kharkov State Academy of Physical Culture, Ukraine

${ }^{3}$ Department Biochemistry, Anatomy and Sports Medicine, Kharkov State Academy of Physical Culture, Ukraine ${ }^{4}$ Department Hygiene and Social Medicine, V. N. Karazin Kharkov National University, Ukraine ${ }^{5}$ Department of Physical Education, Kharkov National Medical University, Ukraine ${ }^{6}$ Department of Social Sciences, Kharkov National Medical University, Ukraine

Authors' Contribution: A - Study design; B - Data collection; C - Statistical analysis; D - Manuscript Preparation; E - Funds Collection.

\begin{tabular}{|c|c|}
\hline \multicolumn{2}{|l|}{ Abstract } \\
\hline Purpose: & $\begin{array}{l}\text { The comparative analysis of the physical development and somatotype of girls and females involved in } \\
\text { dancing and gymnastic sports (acrobatic rock and roll, sports aerobics). }\end{array}$ \\
\hline Material: & $\begin{array}{l}\text { The study involved } 45 \text { girls and females. Group } 1-\text { acrobatic rock and roll }(n=25 \text {, age }-13.00 \pm 0.41 \text { years); } \\
\text { Group } 2 \text { - sports aerobics ( } n=20 \text {, age }-19.70 \pm 0.59 \text { years). It was determined the length and body weight. } \\
\text { It was evaluated the level and harmony of physical development. The bioimpedance method was applied to } \\
\text { determine the composition of muscle and fat tissue, the level of visceral fat. It was evaluated the body mass } \\
\text { index, water composition in the body. The results are evaluated by applying parametric and non-parametric } \\
\text { statistical indicators. }\end{array}$ \\
\hline Results: & $\begin{array}{l}\text { The average level of physical development dominates in athletes. Its specific gravity is: group } 1-(64.00 \pm \\
9.60) \% \text {; group } 2-(50 \pm 11.18) \% \text {. Rather high prevalence of the level below the average: group } 1-(20.00 \\
\pm 8.00) \% \text {; group } 2-(25.00 \pm 9.68) \% \text {. The proportion of athletes with harmonious development was: group } \\
1-(64.00 \pm 9.60) \% \text {; group } 2-(50.00 \pm 11.18) \% \text {. The disharmony of physical development due to overweight: } \\
\text { group } 1-(20.00 \pm 8.00) \% \text {; group } 2-(30.00 \pm 10.25) \% \text {. The disharmony of development due to underweight: } \\
\text { group } 1-(16.00 \pm 7.33) \% \text {; group } 2-(20.00 \pm 8.94) \% \text {. The average values of fat tissue reflect its normal } \\
\text { composition in both groups. In group } 1 \text {, was determined the normal for the age fat composition in }(52.00 \\
\pm 9.99) \% \text {; low level of fat had ( } 48.00 \pm 9.99) \% \text {. In group } 2 \text {, the normal fat composition was found in }(75.00 \pm \\
9.68) \% \text {. The increased fat composition was }(15.00 \pm 7.98) \% \text { of female athletes. The reduced fat composition } \\
\text { was (10.00 } \pm 7.61) \% \text { of female athletes. The level of visceral fat in athletes of group } 2 \text { was within the age } \\
\text { norm. Female athletes of group } 1 \text { were characterized by virtually no visceral fat. The specific gravity of muscle } \\
\text { tissue in all athletes was above the average for this age group. Group water composition in both groups was } \\
\text { average. }\end{array}$ \\
\hline Conclusions: & $\begin{array}{l}\text { Most athletes have an average harmonious physical development. Deviations of physical development are } \\
\text { most often associated with underweight. It is determined the increase in the composition of muscle mass } \\
\text { above the average age standards for all female athletes. The composition of fat tissue in } 52 \% \text { of female athletes } \\
\text { of the younger group corresponded to the average value. The rest of the athletes had a fat composition below } \\
\text { normal. In the older group: } 75 \% \text { of athletes had an average fat composition; } 15 \% \text { of athletes had a reduced } \\
\text { fat composition; } 10 \% \text { of athletes had a high fat composition. It was determined the significant differences } \\
\text { between groups. The female athletes of group } 1 \text { had smaller values of body length, body weight, the specific } \\
\text { gravity of fat tissue and visceral fat, body water composition, and body mass index. Females of group } 1 \\
\text { had a big specific gravity of muscle tissue. The application of the bioimpedance method has significantly } \\
\text { expanded the data obtained in the analysis of anthropometric indicators and indices. This method can be } \\
\text { recommended for monitoring the functional condition of athletes dancing and gymnastic sports. } \\
\text { physical development, somatotype, bioimpedance method, acrobatic rock and roll, aerobics. }\end{array}$ \\
\hline
\end{tabular}

\section{Introduction}

Physical fitness of athletes is one of the main indicators of sporting success. It is determined by the morphofunctional condition - a complex criterion for the interrelation of the structure and function of the organism. The reflection of the structure is the features of physical development. The functional condition is assessed by the level of physical and mental performance. Thus, the study of these components provides information for the analysis

\footnotetext{
(c) Podrigalo L.V., Artemieva H.P., Rovnaya O.A., Panshyna A.D., Ruban L.A., Merkulova T.V., Galashko M.M., Chernukha O.V., 2019 doi:10.15561/20755279.2019.0204
}

and prediction of the athletes' condition.

The necessity to monitor the functional condition of athletes determines the relevance of the selection of informative and valid tests for control. Thus, Volodchenko et al [1] proved the application of biochemical studies of saliva in the kickboxing athletes' condition monitoring. Korobeynikov et al [2] determined the high informational significance of the studies of the psycho-emotional condition of athletes. The results of Podrigalo et al [3] confirmed the high information composition of the physical development indices in predicting the success of 
the martial arts athletes.

The integral criterion of physical development is recognized as the condition of the somatotype. It is estimated by the specific gravity of the main components of the body (the composition of muscle and fat tissue). Currently, the various methods are used to assess the somatotype. The bioimpedance method is one of the most informative and valid ways to assess somatotype.

Dopsaj et al [4] studied the body composition of elite martial arts athletes. It is emphasized that this is one of the main factors of sporting success. The application of discriminant analysis allowed us to create a body structure model reflecting the specifics of martial arts.

The literature review devoted to the analysis of the bioelectrical impedance vector (BIVA) was conducted by Castizo-Olier et al [5]. It was analyzed sources included in the database PubMed, SPORTDiscus and Scopus. BIVA is a new technique which has potential in sports and physical exercise. Kalnina et al [6] confirmed the suitability of the bioimpedance method for population studies. Every fifth child in the sport has a reduced level of body fat. It is proposed to apply this indicator for the prevention of health disorders.

Santos et al [7] conducted a comparative analysis of the elite athletes' body applying bioimpedance and other methods. The bioimpedance method has great informative significance and reliability.

The promising direction of the application of this method is the study of the correlations between the lifestyle characteristics and the athletes' condition. Carvalho et al [8] evaluated the correlations between sports, sleep quality and adolescent eating habits. It was also evaluated the impact of sports activities on weight and body structure. It is proposed to apply the bioimpedance method in complex studies devoted to the study of lifestyle.

The results of Nykanen et al [9] indicate the promise of applying the bioimpedance method in a comprehensive analysis of the nutrition characteristics and motor activity of military personnel. Ramos-Jimenez et al [10] applied the bioimpedance method to analyze the body composition of young people. It was confirmed the proximity of the obtained results by the bioimpedance and densitometry methods. Studies by Koury et al [11] confirmed the effectiveness of the bioimpedance method in assessing the body composition of young athletes. It was confirmed the correlations between biological maturity and body composition.

Ramon Alvero-Cruz et al [12] applied the bioimpedance method for a comparative analysis of changes in the body composition of athletes and nonathletes. Intensive training for 6 weeks led to an increase in fat-free mass in football players.

The comparative analysis of the body composition of men and women football players was performed by Mascherini et al [13]. The application of the bioimpedance method has confirmed that increasing the level of sportsmanship reduces gender differences in body composition.

The results of Meleleo et al [14] confirm the effectiveness of the bioimpedance method in monitoring the athletes' condition. The control during the year confirmed the greater objectivity and reliability of these indicators in comparison with the indices of physical development. Mala et al [15] used the bioimpedance method to evaluate the effectiveness of intensive weight reduction of judo athletes in preparing for competitions.

Dance and gymnastic sports are characterized by intense aerobic loads, combined with high power loads. Chernozub et al [16] confirmed the presence of the expressed effect of loads in these sports on the morphometric characteristics of the athletes' body. This necessitates the analysis of the specific gravity of muscle and fat tissue. These morphological indicators illustrate the condition of power, power endurance, and other important physical qualities.

The purpose of this work was a comparative analysis of the physical development and somatotype of girls and females involved in dance and gymnastic sports (acrobatic rock and roll, sports aerobics).

\section{Materials and methods}

\section{Participants.}

The study involved 45 girls and females, divided into two groups depending on the sport. Group $1-25$ women of acrobatic rock and roll, age $(13.00 \pm 0.41)$ years. Group 2 - 20 girls who were engaged in sports aerobics, age (19.70 $\pm 0.59)$ years. Differences in age are significant $(p<0.01)$. The level of sportsmanship in group 1: 76\% are Candidate Master of Sports, $24 \%-1$ athletic title. The level of sportsmanship in group 2: 5\% - International Master of Sport, $55 \%$ - Candidate Master of Sports, $40 \%$ - athletes 1-2 athletic titles. All athletes gave informed consent to participate in the research and the use of personal data.

Design of the study.

The design of the study presupposed the definition of anthropometric indices, components of the somatotype, the calculation of morphometric indices and indices applying special formulas.

The determination of mass and length of the body was carried out in accordance with international standards [17]. The evaluation of the level and harmony of physical development was carried out applying official standards for school-age children [18] and young people [19].

The bioimpedance method was applied to assess the characteristics of the somatotype. It was applied the body composition monitor OMRON BF-511 (Japan). It was determined the specific gravity of muscle and fat tissue, the percentage of visceral fat, the basal metabolic rate value.

The calculation of body mass index is carried out by the formula:

$$
\mathrm{BMI}=\mathrm{BM} / \mathrm{BL}^{2}(1) \text {, }
$$

where BMI - body mass index, $\mathrm{kg} / \mathrm{m}^{2}, \mathrm{BM}$ - body mass (kg), BL - body length (m).

In people older than 18 years, 19-24 values are considered as the norm, and in schoolchildren - according to standardized normative values [20].

The water composition in the body was calculated by 
the formula:

$\mathrm{WCB}=10.313+0.252 * \mathrm{BM}+0.154 * \mathrm{BL}(2)$,

where WCB - the water composition in the body, 1 , $\mathrm{BM}$ - the body weight, $\mathrm{kg}, \mathrm{BL}$ - the body length (m).

The analysis of the results of the water composition was performed according to standardized standard values [21].

\section{Statistical analysis}

Statistical analysis of the obtained data was carried out applying licensed MS Excel. It was determined the descriptive statistics of the following indicators: arithmetic average, standard deviation, and error of the mean. The relative indicators determined the prevalence of the trait and its error. The significance of differences in the groups was evaluated applying the parametric Student's t-test $(\mathrm{t})$ and the non-parametric Wilcoxon-Mann-Whitney test (U)

\section{Results.}

The results of anthropometric indicators and components of the somatotype are presented in table 1 .

Group analysis of the main anthropometric parameters demonstrated that the body length of the athletes refers to the average level, the body weight of the athletes corresponds to the length of the body. The individual analysis revealed that the average level of physical development prevails in athletes. Its specific gravity is $(64.00 \pm 9.60) \%$ in group 1 and $(50.00 \pm 11.18) \%$ in group 2. The quite high prevalence is below average, respectively $(20.00 \pm 8.00) \%$ and $(25.00 \pm 9.68) \%$. The level above the average is set for $(8.00 \pm 5.43) \%$ of female athletes of group 1 and $(15.00 \pm 7.98) \%$ of female athletes of group 2. The low level of physical development is set, respectively, at $(8.00 \pm 5.43) \%$ and $(5.00 \pm 4.87) \%$. There were no athletes with a high level in group 1 . In group 2 , the specific gravity of athletes with a high level was (5.00 $\pm 4.87) \%$.

Similar results were obtained in the analysis of harmony. The specific gravity of athletes with harmonious development was $(64.00 \pm 9.60) \% 1$ group and $(50.00$ $\pm 11.18) \% 2$ groups. The disharmony of physical development due to excess body weight is set in (20.00 $\pm 8.00) \% 1$ group and $(30.00 \pm 10.25) \% 2$ group. The disharmony of development due to the lack of body weight was found in $(16.00 \pm 7.33) \% 1$ group and $(20.00$ $\pm 8.94) \% 2$ groups.

Average body mass index values illustrate the normal level of this indicator. The individual analysis of body mass index demonstrated that most of the female athletes had normal physical development. Their specific weight was $(56.00 \pm 9.93) \% 1$ group and $(85.00 \pm 7.98) \% 2$ group. In group 1, there was a deviation of body mass index to a deficit $(32.00 \pm 9.33) \%$ and inanition of the body $(12.00 \pm 6.50) \%$. In group 2 , underweight was found in $(10.00 \pm 6.71) \%$ and overweight in $(5.00 \pm 4.87) \%$.

The average values of fat tissue reflect its normal composition in both groups. The individual analysis confirmed the similarity of the results to body mass index. In group 1, the normal for the age fat composition was set at $(52.00 \pm 9.99) \%,(48.00 \pm 9.99) \%$ had a low-fat level. In group 2, the normal composition was found in $(75.00$ $\pm 9.68) \%$. $(15.00 \pm 7.98) \%$ of female athletes had a high fat composition. $(10.00 \pm 7.61) \%$ of female athletes had a reduced fat composition.

The visceral fat level in athletes of group 2 was within the age norm. Female athletes of group 1 were characterized by no visceral fat.

The specific gravity of muscle tissue in all athletes was above the average for this age group.

Group water composition in both groups was average. The individual analysis showed that in group $1(80.00$ $\pm 8.00) \%$ of female athletes had an average water composition, $(12.00 \pm 6.50) \%$ of female athletes were deficient in water composition, $(8.00 \pm 5.43) \%$ of female athletes had excessive water composition. In group 2, these weights were, respectively, $(70.00 \pm 10.25) \%,(5.00$ $\pm 4.87) \%$ and $(25.00 \pm 9.68) \%$. The basal metabolic rate did not have significant differences between the groups.

It was determined the significant differences between the groups for most of the studied parameters. This is confirmed by parametric and non-parametric criteria. The

Table 1. The results of anthropometric indicators and components of the athletes' somatotype.

\begin{tabular}{lll}
\hline Indicator & $\mathbf{1}$ group $(\mathbf{n = 2 5})$ & $\mathbf{2}$ group $(\mathbf{n = 2 0})$ \\
\hline Body length, cm & $154.30 \pm 2.14^{1}$ & $165.00 \pm 1.36$ \\
Body mass, kg & $44.45 \pm 2.14^{1}$ & $57.20 \pm 1.72$ \\
Specific gravity of fat tissue,\% & $17.11 \pm 8.42$ & $27.34 \pm 8.91$ \\
Specific gravity of muscle tissue,\% & $35.40 \pm 10.69$ & $30.45 \pm 9.20$ \\
Basal metabolic rate value, kcal & $1284.32 \pm 20.64$ & $1223.87 \pm 65.87$ \\
Body water composition, I & $21.75 \pm 0.54^{1}$ & $24.98 \pm 0.43$ \\
The specific gravity of visceral fat,\% & 0.00 & $2.95 \pm 3.38$ \\
Body mass index, $\mathrm{kg} / \mathrm{m}^{2}$ & $16.87 \pm 0.17^{1}$ & $21.24 \pm 0.41$ \\
\hline
\end{tabular}

Note. 1 - the differences between groups are significant $(p<0.01)$. 
female athletes of group 1 had smaller body lengths $(\mathrm{t}=$ $4.21, \mathrm{p}<0.01 ; \mathrm{U}=96, \mathrm{p}<0.01)$, body mass $(\mathrm{t}=4.64, \mathrm{p}$ $<0.01 ; \mathrm{U}=86, \mathrm{p}<0.01$ ), specific gravity of fat tissue ( $\mathrm{U}$ $=60, \mathrm{p}<0.01)$ and visceral fat $(\mathrm{t}=11.08, \mathrm{p}<0.01 ; \mathrm{U}=3$, $\mathrm{p}<0.01)$, body water composition $(\mathrm{t}=5.50, \mathrm{p}<0.01 ; \mathrm{U}=$ $0, \mathrm{p}<0.01)$, body mass index $(\mathrm{t}=4.81, \mathrm{p}<0.01 ; \mathrm{U}=8, \mathrm{p}$ $<0.01)$. The significant increase of the muscle tissue was confirmed according to the specific gravity in athletes of the group $1(\mathrm{U}=56, \mathrm{p}<0.01)$.

\section{Discussion}

Comparison of the athletes' condition of related sports is widely applied in sports science. This allows to determine the specific effect of the sport on the athletes' body, to select the most informative tests and functional tests. Podrigalo et al [22] conducted a comparison of the psychophysiological characteristics of athletes of different types of martial arts. The analysis allowed to identify the most informative tests suitable for monitoring the functional condition of athletes.

The results of Romanenko et al [23] confirmed the suitability of determining the choice reaction time for screening selection in martial arts.

Rovnaya et al [24] considered the specifics of synchronized swimming. The authors tested a system of tests to assess the functional condition of the athletes' respiratory system. It was confirmed significant differences depending on the level of skill.

In our study, we evaluated the physical development of female athletes of acrobatic rock and roll and sports aerobics. They belong to the group of dance and gymnastic sports but have significant differences in the level of physical activity. There are differences in the degree of development of physical qualities which are important for success (power, endurance, speed). The condition of the somatotype can be assessed as a complex characteristic, reflecting the interrelation of these qualities. This significantly increases the information composition of this assessment.

A similar study was conducted by Durkalec-Michalski et al [25]. The authors studied the correlations between body composition indicators and physical performance.

Analysis of the main anthropometric parameters allows to conclude that the average level of athletes' physical development is dominant. Contrast deviations are quite rare. This is due to the peculiarities of sports, their command character. The absence of contrast differences in the physical development of athletes improves the aesthetic perception of the team.

Similar results were obtained by Reguli et al [26]. The authors analyzed the body composition of aikido athletes. It was determined the proximity of the basic parameters to the standards typical for non-athletes.

Among female athletes dominated persons with harmonious physical development. In our opinion, this reflects the aesthetic orientation of studied sports. Harmonious physical development implies the optimal proportions of the human body. At the same time, disharmony is established due to underweight and due to overweight. Perhaps this is due to the peculiarities of lifestyle, the maintenance of reduced diets, the level of physical activity during training.

This assumption is supported by the results of determining body mass index. The majority of athletes were characterized by a normal level of this indicator. However, in group 1 there was a significant deviation to deficiency, there were athletes with inanition of the body. Group 2 had the same tendency, although it was less expressed. In our opinion, this may be due to the age of the participants. The females of the group 2 consciously chose a nutrition strategy. In addition, the specifics of acrobatic rock and roll could necessitate a tight control of body weight. Less weight increases the performance of acrobatic elements.

The use of bioimpedance method allowed us to significantly expand the data obtained in the analysis of body mass index. In this, our results coincide with the data of Girsh et al [27]. The authors emphasize the promising application of the bioimpedance method in sports medicine, its advantages over the definition of body mass index.

The composition of muscle and fat tissue should be assessed as the primary prognostic indicator. The results obtained coincide with the analysis of body mass index, confirm earlier assumptions. Athletes have a tendency to reduce the level of fat in the body. This tendency is more pronounced in group 1. The results are closely correlated with results of Kalnina et al [6]. In our opinion, this illustrates the effect of intense physical loads on the body.

Similar data are given by Gutierrez et al [28]. The authors evaluated the effect of regular physical exercises on adolescent body composition. Non-athletes had a higher body fat composition.

At the same time (considering the age of female athletes in group 1), these data can be assessed as a risk factor for impaired sexual maturation. The almost complete absence of visceral fat in athletes of group 1 should also be assessed as a risk factor for health.

The muscle composition above average is the result of intense training. It reflects a fairly high level of sportsmanship athletes.

Similar results were obtained in da Silva Morais et al [29]. The authors studied the component composition of the body to assess the performance of judo athletes. It is concluded that the features of the somatotype are fundamentally important for increasing physical performance.

Similar results are obtained by Delaney et al [30]. The purpose of the authors was to determine the most effective method for quantifying changes in muscle mass in rugby athletes. It was confirmed the high informational content of bioelectrical impedance analysis, determination of muscle mass index and prediction equations based on the skinfold thickness.

Determining the level of water composition in the body of athletes allows to conclude about the normal hydration of the body. In addition, this once again confirms the assumptions made about the proximity of the condition 
of the somatotype to the average. Individual deviations caused by deficit or excess of water, perhaps stipulated by the peculiarities of maintaining the drinking regime.

Similar data were obtained by Carrasco-Marginet et al [31]. They used the bioimpedance method to assess the condition of synchronized swimming athletes. It is confirmed the pronounced effect of physical loads on the condition of homeostatic hydration.

The basal metabolic rate reflects the energy cost of maintaining the homeostasis of the body. The proximity of these values in groups should be evaluated as evidence of the stability of the condition, the absence of serious violations. The absence of differences between groups can be considered as evidence of the normal course of growth and development in more young athletes.

The results of the comparison of the studied parameters indicate a higher level among experienced female athletes. This can be explained by a number of factors. First of all, it is age, the experience of training, the condition of the processes of growth and development, especially lifestyle.

At the same time, the comparison suggests the importance of applying the bioimpedance method. This correlates with the available literary data. The results obtained by Nascimento-Carvalho et al [32] confirmed the perspective of applying the bioimpedance method for assessing the athletes' preparedness in martial arts.

The bioimpedance method confirms the assumptions made in the analysis of physical development. For younger athletes, intensive training leads to a reduction in fat tissue. This is particularly evident when assessing the level of visceral fat. Fat tissue is one of the main water depots in the body. This leads to a decrease in its composition in young athletes. This condition of athletes (considering their age) should be assessed as a risk factor for health.

Similar results were obtained by Salazar Martinez et al. [33]. The authors conducted an analysis of the functional condition of young football players. The design of the study included the determination of the specific gravity of body fat applying an OMRON analyzer. It was determined that young athletes had an average level of fat, characteristic for this age group (6-14\%).

\section{Conclusions}

The analysis confirmed that most athletes have moderate harmonious physical development. This is due to the peculiarities of sports, their command character and reflects the aesthetic orientation of the sports studied. Deviations of physical development are most often associated with underweight. This is confirmed by the analysis of body mass index. The application of the bioimpedance method defined an increase in the muscle mass composition above the average age standards for all athletes. The composition of fat tissue in $52 \%$ of female athletes in the younger group corresponded to the average value, in the rest it was below the norm. In the older group, $75 \%$ of athletes had an average fat composition, $15 \%$ of female athletes had a lower fat composition, and $10 \%$ of female athletes had an increased fat composition. It was determined significant differences between groups. The female athletes of group 1 had fewer values of body length, body weight, specific weight of fat tissue and visceral fat, body water composition, and body mass index. Female group 1 had a higher specific gravity of muscle tissue. The condition of the somatotype components illustrates the effect of physical loads on the body, reflects the specifics of the studied sports.

The application of the bioimpedance method has significantly expanded the data obtained in the analysis of anthropometric indicators and indices. This method can be recommended for monitoring the functional condition of athletes involved in dancing and gymnastic sports.

\section{Conflict of interest}

The authors declare no conflict of interest.

\section{References}

1. Volodchenko OA, Podrigalo LV, Iermakov SS, Żychowska MT, Jagieło W. The Usefulness of Performing Biochemical Tests in the Saliva of Kickboxing Athletes in the Dynamic of Training. BioMed Research International, 2019;2019:1-7. https://doi.org/10.1155/2019/2014347

2. Korobeynikov G, Korobeinikova L, Mytskan B, Chernozub A, Cynarski WJ. Information processing and emotional response in elite athletes. Ido Movement for Culture Journal of Martial Arts Anthropology, 2017:41-50. https://doi.org/10.14589/ido.17.2.5

3. Podrigalo L, Cynarski WJ, Rovnaya O, Volodchenko O, Halashko O, Volodchenko J. Studying of physical development features of elite athletes of combat sports by means of special indexes. Ido Movement for Culture Journal of Martial Arts Anthropology, 2019:51-57. https://doi.org/10.14589/ido.19.1.5

4. Dopsaj M, Markovic M, Kasum G, Jovanovic S, Koropanovski N, Vukovic M, et al. Discrimination of Different Body Structure Indexes of Elite Athletes in Combat Sports Measured by Multi Frequency Bioimpedance Method.
International Journal of Morphology, 2017;35:199-207. https://doi.org/10.4067/S0717-95022017000100033

5. Castizo-Olier J, Irurtia A, Jemni M, Carrasco-Marginet M, Fernández-García R, Rodríguez FA. Bioelectrical impedance vector analysis (BIVA) in sport and exercise: Systematic review and future perspectives. Plos One, 2018;13:e0197957. https://doi.org/10.1371/journal.pone.0197957

6. Kalnina L, Sauka M, Timpka T, Dahlström Ö, Nylander E, Selga G, et al. Body fat in children and adolescents participating in organized sports: Descriptive epidemiological study of 6048 Latvian athletes. Scandinavian Journal of Public Health, 2015;43:615-22. https://doi.org/10.1177/1403494815581696

7. Santos DA, Silva AM, Matias CN, Magalhães JP, Minderico CS, Thomas DM, et al. Utility of novel body indices in predicting fatmass in elite athletes. Nutrition, 2015;31:948-54. https://doi.org/10.1016/j.nut.2015.02.003

8. Carvalho AS, Fernandes AP, Gallego AB, Vaz JA, Vega MS. The relation of sports with sleep quality and anthropometric measures at secondary schools. Journal of Sport and Health Research. 2019; 11(1): 91-106. 
9. Nykanen T, Pihlainen K, Santtila M et al. Diet Macronutrient Composition, Physical Activity, and Body Composition in Soldiers During 6 Months Deployment. Military Medicine. 2019; 184(3-4): E231-E237.

10.Ramos-Jimenez A, Hernandez-Torres RP, Murguia-Romero M. Anthropometric equations for calculating body fat in young adults. Archivos Latinoamericanos de Nutricion. 2018; 68(2): 111-121.

11.Koury JC, Ribeiro MA, Massarani FA, Vieira F, Marini E. Fat-free mass in adolescent athletes: Accuracy of bioimpedance equations and identification of new predictive equations. Nutrition, 2019;60:59- 65 . https://doi.org/10.1016/j.nut.2018.09.029

12.Alvero Cruz JR, Ronconi M, García Romero JC, Carrillo de Albornoz Gil $M$, Jíménez López $M$, Correas Gómez L, et al. Cambios de la composición corporal tras un periodo de desentrenamiento deportivo. Nutrición Hospitalaria, 2017;34:632. https://doi.org/10.20960/nh.618

13.Mascherini G. Differences between the sexes in athletes body composition and lower limb bioimpedance values. Muscles, Ligaments and Tendons Journal, 2017;7:573. https://doi.org/10.11138/mltj/2017.7.4.573

14. Meleleo D, Bartolomeo N, Cassano L, Nitti A, Susca G, Mastrototaro G, et al. Evaluation of body composition with bioimpedence.Acomparison between athletic and non-athletic children. European Journal of Sport Science, 2017;17:710-9. https://doi.org/10.1080/17461391.2017.1291750

15.Mala L, Maly T, Zahalka F e.a. Changes in body composition due to weight reduction by elite youth judo athletes in short period pre-competition. Archives of Budo Science of Martial Arts and Extreme Sports. 2016; 12: 197-203.

16.Chernozub A, Imas Y, Korobeynikov G, et al. The influence of dance and power fitness loads on the body morphometric parameters and peculiarities of adaptive-compensatory reactions of organism of young women. Journal of Physical Education and Sport. 2018; 18(2), 955-960.

17.International Standards for Anthropometric Assessment, ISAK; 2001

18.Serdiuk AM. Standards for assessing the physical development of schoolchildren, Kiev: Tale; 2010. (in Ukrainian)

19. Tegako LI, Marfina OV. Practical anthropology. Rostov on Don: Phoenix; 2003. (in Russian)

20.Pol'ka NS, Platonova AG, Iackovs'ka NIa. Screeningassessment of the physical development of children aged 6-17 by the Ketley index. Informacionnoe pis'mo, 2012; 60: 1-10. (in Russian)

21.Platonova AG, Iackovs'ka NIa, Pashins'ka SL. Quantitative and qualitative determination of water content in the organism of children 6-17 years. Informacionnoe pis'mo, 2012; 157: 1-10. (in Russian)

22.Podrigalo L, Iermakov S, Romanenko V, Rovnaya O, Tropin Y, Goloha V, Halashko O. Psychophysiological features of athletes practicing different styles of martial arts - the comparative analysis. International Journal of Applied Exercise Physiology, 2019;8(1):84-91. https://doi.org/10.30472/ijaep.v8i1.299

23.Romanenko V, Podrigalo L, Iermakov S, Rovnaya O, Tolstoplet E, Tropin Y, et al. Functional state of martial arts athletes during implementation process of controlled activity comparative analysis. PhysicalActivity Review, 2018;6:87-93. https://doi.org/10.16926/par.2018.06.12

24.Rovnaya OA, Podrigalo LV, Aghyppo OY, Cieślicka M, Stankiewicz B. Study of Functional Potentials of Different Portsmanship Level Synchronous Swimming Sportswomen under Impact of Hypoxia. Research Journal of Pharmaceutical Biological and Chemical Sciences. 2016; 7(4):1210-1219.

25.Durkalec-Michalski K, Podgorski T, Sokolowski M. Relationship between body composition indicators and physical capacity of the combat sports athletes. Archives of Budo. 2016;12: 247-256.

26.Reguli Z, Bernacikova M, Kumstat M. Anthropometric Characteristics and Body Composition in Aikido Practitioners. International Journal of Morphology. 2016; 34(2): 417-423. https://doi.org/10.4067/S0717-95022016000200001

27.Girsh YV, Gerasimchik OA. The role and place of bioimpedance analysis assessment of body composition of children and adolescents with different body mass. Byulleten Sibirskoy Meditsiny. 2018; 17(2): 121-132. https://doi.org/10.20538/1682-0363-2018-2-121-132

28.Gutiérrez R, Aldea L, Cavia MDM, Alonso-Torre SR. Relation between the body composition and the sports practice in teenager. Nutr Hosp, 2015;32:336-45. https://doi.org/10.3305/nh.2015.32.1.9112

29.da Silva Morais TM, Mendes Silva Santos VR, de Sousa Sa, OM. Nutritional diagnosis of Piaui men's judo team. RBNERevista Brasileira de Nutricao Esportiva. 2017; 11(66): 682688.

30.Delaney JA, Thornton HR, Scott TJ, Ballard DA, Duthie GM, Wood LG, et al. Validity of Skinfold-Based Measures for Tracking Changes in Body Composition in Professional Rugby League Players. International Journal of Sports Physiology and Performance, 2016;11:261-6. https://doi.org/10.1123/ijspp.2015-0244

31.Carrasco-Marginet M, Castizo-Olier J, RodríguezZamora L, Iglesias X, Rodríguez FA, Chaverri D, et al. Bioelectrical impedance vector analysis (BIVA) for measuring the hydration status in young elite synchronized swimmers. Plos One, 2017;12:e178819. https://doi.org/10.1371/journal.pone.0178819

32.Nascimento-Carvalho B do, Mayta MAC, Izaias JE, Doro MR, Scapini K, Caperuto E, et al. Cardiac sympathetic modulation increase after weight loss in combat sports athletes. Revista Brasileira de Medicina Do Esporte, 2018;24:413-7. https://doi.org/10.1590/1517-869220182406182057

33.Salazar Martinez JL, Jimenez TJO. Evaluation of maximum oxygen consumption (VO2max) and percentage of fat in young footballers. Viref-Revista de Educacion Fisica. 2018; 7(1): 50-86. 


\section{Information about the authors:}

Podrigalo L.V.; (Corresponding author); http://orcid.org/0000-0002-7893-524X; I.podrigalo@mail.ru; Kharkov State Academy of Physical Culture; Klochkovskaya str. 99, Kharkov, 61022, Ukraine.

Artemieva H.P.; http://orcid.org/0000-0002-6965-4972; galina9767@gmail.com; Kharkov State Academy of Physical Culture; Klochkovskaya str. 99, Kharkov, 61022, Ukraine.

Rovnaya O.A.; http://orcid.org/0000-0003-1519-5632; rovnayaolga77@ukr.net; Kharkov State Academy of Physical Culture; Klochkovskaya str. 99, Kharkov, 61022, Ukraine.

Panshyna A.D. ; http://orcid.org/0000-0002-4095-1316; galina9767@gmail.com; Kharkov State Academy of Physical Culture; Klochkovskaya str. 99, Kharkov, 61022, Ukraine.

Ruban L.A.; http://orcid.org/0000-0002-7192-0694; larisaruban@gmail.com; Kharkov State Academy of Physical Culture; Klochkovskaya str. 99, Kharkov, 61022, Ukraine.

Merkulova T.V.; http://orcid.org/ 0000-0003-2362-9226; mvtet@ukr.net; V. N. Karazin Kharkov National University; 4 Svobody Sq., Kharkov, 61022, Ukraine.

Galashko M.M. ; http://orcid.org/0000-0001-5278-9806; galashko_max@mail.ru; Kharkov National Medical University, Nauki av., 4, Kharkov, 61022, Ukraine.

Chernukha O. V.; https://orcid.org/0000-0003-2151-2067; nymbis@gmail.com; Department of Social Sciences, Kharkov National Medical University; Nauki av., 4, Kharkov, 61022, Ukraine.

\section{Cite this article as:}

Podrigalo LV, Artemieva HP, Rovnaya OA, Panshyna AD, Ruban LA, Merkulova TV, Galashko MM, Chernukha OV. Analysis of the physical development and somatotype of girls and females involved into dancing and gymnastic sports. Physical education of students, 2019;23(2):75-81. https://doi.org/10.15561/20755279.2019.0204

The electronic version of this article is the complete one and can be found online at: https://sportedu.org.ua/index.php/PES/issue/archive

This is an Open Access article distributed under the terms of the Creative Commons Attribution License, which permits unrestricted use, distribution, and reproduction in any medium, provided the original work is properly cited http://creativecommons.org/licenses/by/4.0/deed.en

Received: 20.03.2019

Accepted: 15.04.2019; Published: 28.04.2019 